\title{
Vernacular Architecture - Earthen Buildings in Central and EAsten Europe
}

\author{
Popescu Mara ${ }^{1}$, Zsuzsanna Tasnádi $^{2}$ \\ ${ }^{1}$ Architect, PhD.c. \\ Romanian National Commission for UNESCO \\ ICOMOS, Europa Nostra and Future for Religious Heritage \\ arch.mara.popescu@outlook.com \\ ${ }^{2}$ Néprajzi Múzeum, Budapest, Hungary \\ tasnadi@neprajz.hu
}

\begin{abstract}
The revival of earthen architecture in the last thirty years has allowed, finally, a project flowering compelling challenges facing society in the XXI century. This earthen modern architecture is determined by the environmental quality of the material: energetic, economical (material widely available) and aesthetical. This new architecture meets also a return to logically reasoned and reasonable by upgrading local resources, not only material available in situ, but also of knowledge and human resources replies architectural and construction in the territories and people they inhabit.
\end{abstract}

Keywords: vernacular architecture, Central and Eastern Europe, earthen buildings

\section{INTRODUCTION}

In Central and Eastern Europe there is a diversity of forms of earth architecture and variety of construction techniques.

Earth has been used since ancient times, possibly the first building material to build walls with joint solutions and to create simple and mortar or used as insulating material.

The use of earth as a building material was not considered a modern method for the local, national and international, and therefore, at least at European level this architectural heritage is still almost unknown. In Hungary and the Czech Republic there are thematic studies, little known international architectural environment.

The earthen constructions as a solution for the construction of vernacular buildings was not a solution in an environment dominated by wood construction. But these structures that largescale use wood were plastered on the inside and out derivative of the ground, having beaten earth floors and the roof was insulated himself with a considerable layer of mixed soil.

Its revival began in the eighteenth century when factors such as deforestation and the lack of wood in certain areas and prohibits cutting trees on large areas led her reassessment.

Wood construction technique combined with earth, but remains often hidden behind the plaster, usually in whitewashed dwellings. Technology and earthen architecture can be ordered 
in two groups, depending on the nature of the support structure of wood. In this context we can characterize as a permanent structure that has the function of supporting wood and earth is only a filler or auxiliary if the wood loses function when the earth wall is finished.

The literature describes several examples of techniques:

a) Construction of earth with permanent wooden structure. Wooden buildings with permanent structure may have walls with vertical posts and horizontal strips of straw with a network continues covered with a layer of earth on both sides; vertical pillars and walls with vertical strips dressed in the ground at the end; vertical pillars and walls with horizontal strips of thick vegetable woven coated with layers of earth; or walls made of wood and stuffing willow twigs or sticks also plastered on both sides with earth.

b) Earthen constructions with auxiliary timber frame. In buildings with auxiliary wooden structure, used during construction of the building, can be found walls with post-and-beams structure filled with cob masonry; Although plastered walls with vertical poles which have on both sides a thick layer of earth mixed with straw or horizontal branches interspersed between poles, to have the earth a better grip.

c) Earth as filler. Woven covered by earth were used to build walls, combined to create double formwork structure filled with earth. The structure will be covered with earth and the filling of two panels of willow twigs or sticks, then plastered on both sides. [1][2][14]

\subsection{Earthen vernacular architecture in Romania}

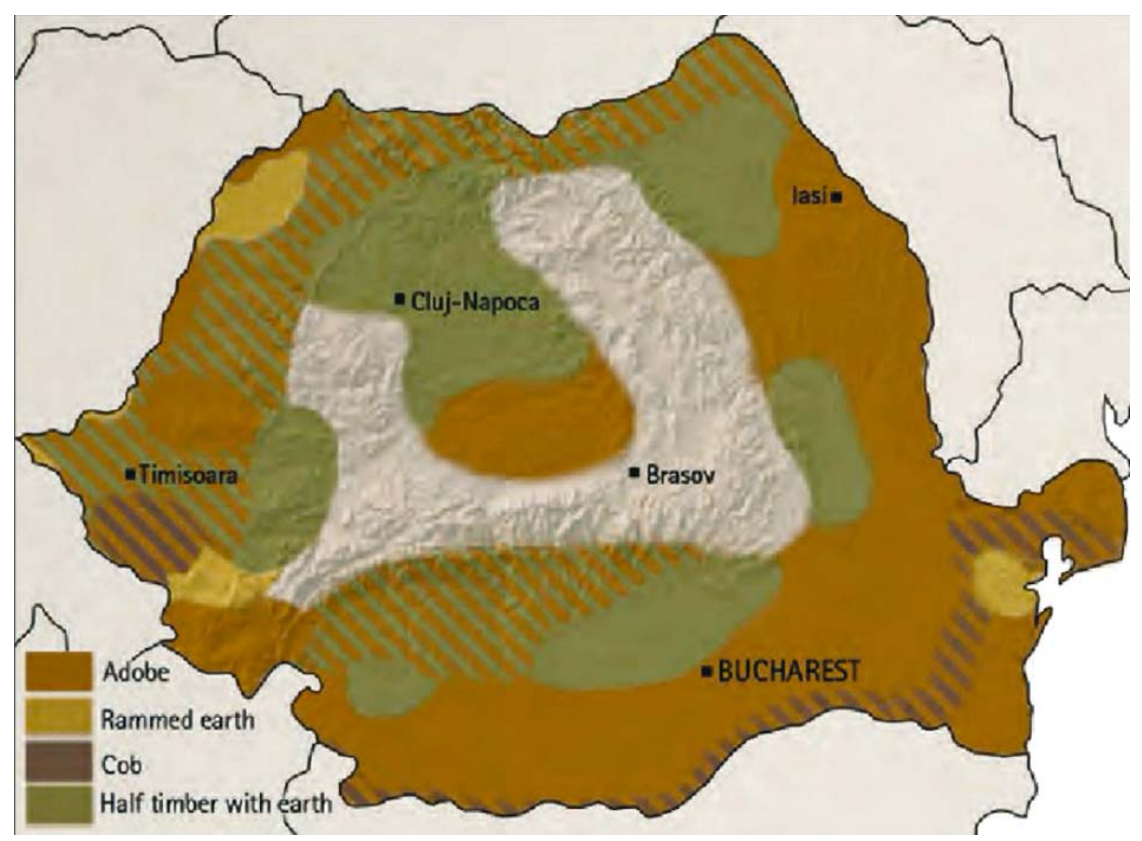

Fig.1. Map of Hungary where we can find earthen buildings

The relief of the country is divided between plains, hills and mountains. Earthen architecture follows closely the geography with a greater concentration of earthen constructions in the plains and lower in the hills and mountains in the area. 
Earthen architecture is found throughout the country with a more visible presence of adobe buildings in Moldavia and Dobrogea. Because of this wood in abundance, Romania had a wood culture predominating, although the earth was always a material that has had its place in any building. Following the massive deforestation in the last 150 years, the forests have been replaced by vast plains that determined the appearance of buildings made of adobe bricks, sometimes of cob. In two-third of the municipalities in Romania, we can find many earthen houses or houses where earth was used for construction or completing a secondary role.

Most of the earthen buildings belong to the vernacular architecture. In the outdoor museums throughout the country (the Village Museum in Bucharest, Ramnicu Valcea, Sibiu, Pitesti etc.) it can be found examples of rural vernacular architecture. These ethnographic museums are aimed at collecting the most representative households in the surrounding territories and usually contain houses made of earth or where an earthen plaster was used. Protected urban areas with dense monuments or with a specific purpose can include mansions made with earth from the nineteenth century.

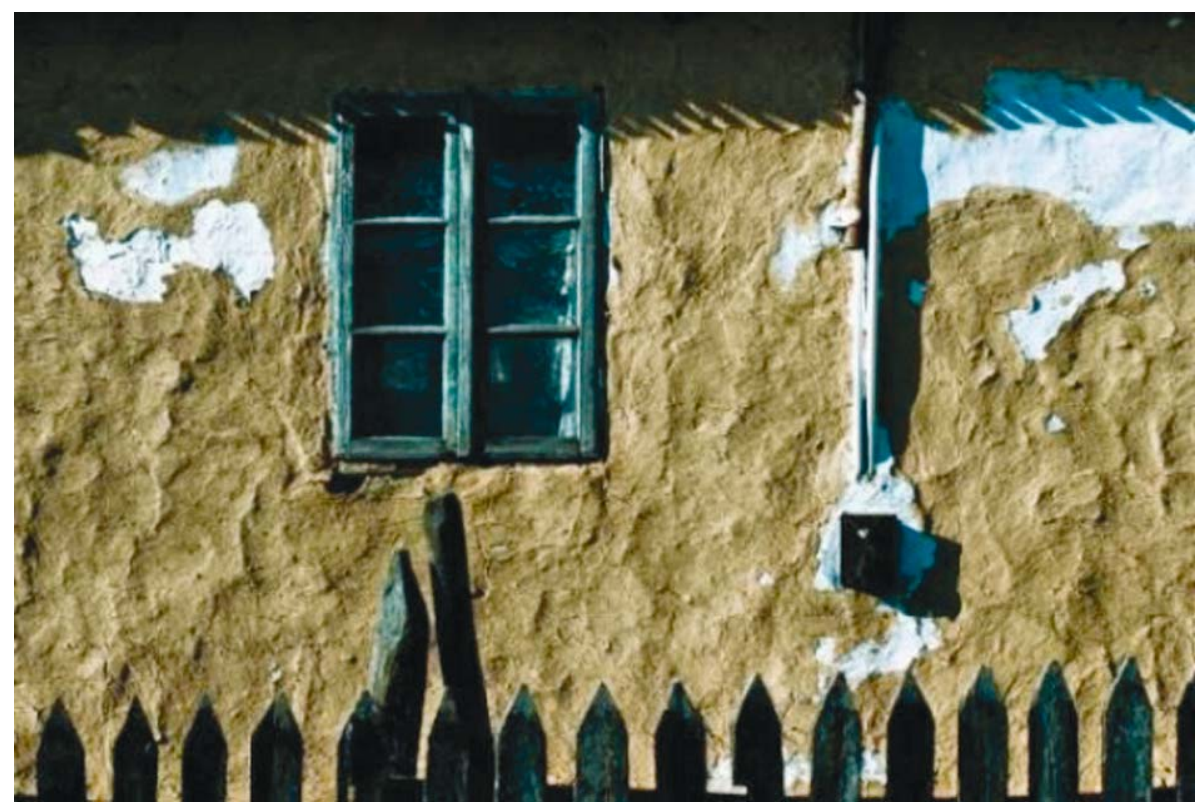

Fig.2. Detail of an earthen building

The protection measure is not applied to villages, where the majority of earthen architecture still exists. The geographic spread of the earthen constructions makes the vernacular heritage to be still inhabited and used by people. Uncontrolled upgrading or expanded abandonment makes these constructions to lose its original character.

Earthen architecture in Romania is more visible in the east and southeast of the country, in areas like Moldavia and Dobrogea. After expert appreciations, about $60-70 \%$ of the houses are made of adobe in Moldova.

Most of the buildings of adobe are found in poor households, poverty still being a stigma associated with this type of construction, giving an undeserved shadow for earthen architecture, a common opinion of public and also specialists. Owners generally want to get rid of adobe 
buildings instead of conserving it, and the earthen constructions and techniques are barely mentioned in books and research works of architecture. A legal framework, with technical rules from the 50's, which are considered outdated, also confers a sense of disbelief. Organic architecture under which these walls bring benefits, makes some urban residents to accept only adobe buildings for recreation facilities (secondary residence, restaurant, etc.), but, still, are determined to reject the idea of having unprocessed earth in their permanent residences. In rural areas they are still building with earth also because of the low price of adobe bricks, 7 times lower than modern bricks.

Construction technique with earth in the hill side areas is based on plastered trellis (cob), mostly found in the Sub-Carpathian area and in the high hills of Moldavia and Oltenia. The technique of rammed earth can be found in towns in northern Moldavia. The houses have wooden planks arranged vertically on them, making it difficult to differentiate between homes made entirely of wood and those that have only the skeleton of wood and filling of bricks, adobe bricks or cob ones.

Houses of Dobrogea area have thick walls and well insulated ceilings with reeds covered by a thick layer of cob. In the winter, here the climate is cold, windy and summer is very hot. Adobe bricks dried in the sun and built in layers have a stacking similar to blocks of regular bricks, which is the most common technique. The houses are characterized by a foundation made of stone, a wooden roof and a single level. Existing and bearing wooden structure, which supports the adobe, changes the name of art in cob.

Pressed earthen bricks are no longer used in the country since the two presses of this kind, one in Brasov and one in Botosani are no more.

Another type of earthen brick, called Gypsy, similar to those of unprocessed earth is produced by Roma communities, with clay and sand, burned in a makeshift furnace at a relatively low temperature. Brick is poor quality, but commonly used because of its low price.

Generally speaking, these earthen buildings have survived the flood and moisture better, which washed the earth, saving the wooden structure and making it possible to repair the building.

In the south of Romania there is a technique in which the walls are made of clay with brick or stone fragments, compacted in a framework. This presence of this technique is explained by the lack of wood in lowlands. Quality is very poor. Compared with the construction type of cob where supporting structure is made of wood and filling of earth, structural problems are different. The quality of the material (mixture of clay) is important for a good execution of work, but the technique requires a minimum of knowledge: to prevent cracks due to drying between successive layers of earth compacted, to make the corners of the building, to protect it from rain and water which infiltrates from the soil, to make the holes for the windows/door. Speaking about the technique used in the south is obvious that it must, above all, have also an appropriate behaviour at earthquakes. It is related, firstly, to the quality of the material and its resistance to certain requirements.

Romania is one of the European countries with a rich depository rural sector, still, an immovable cultural heritage, even if the value is not exceptional individual, it represents the value of the group, a major repository of community and identity specifics. The lack of interest in protecting and preserving the architectural heritage comes, to a large extent, to the lack of consciousness of the importance that it has for the local and national identity.

$[1][2][4][5][6][7][8][9][11][14]$ 


\subsection{Earthen vernacular architecture in Hungary}

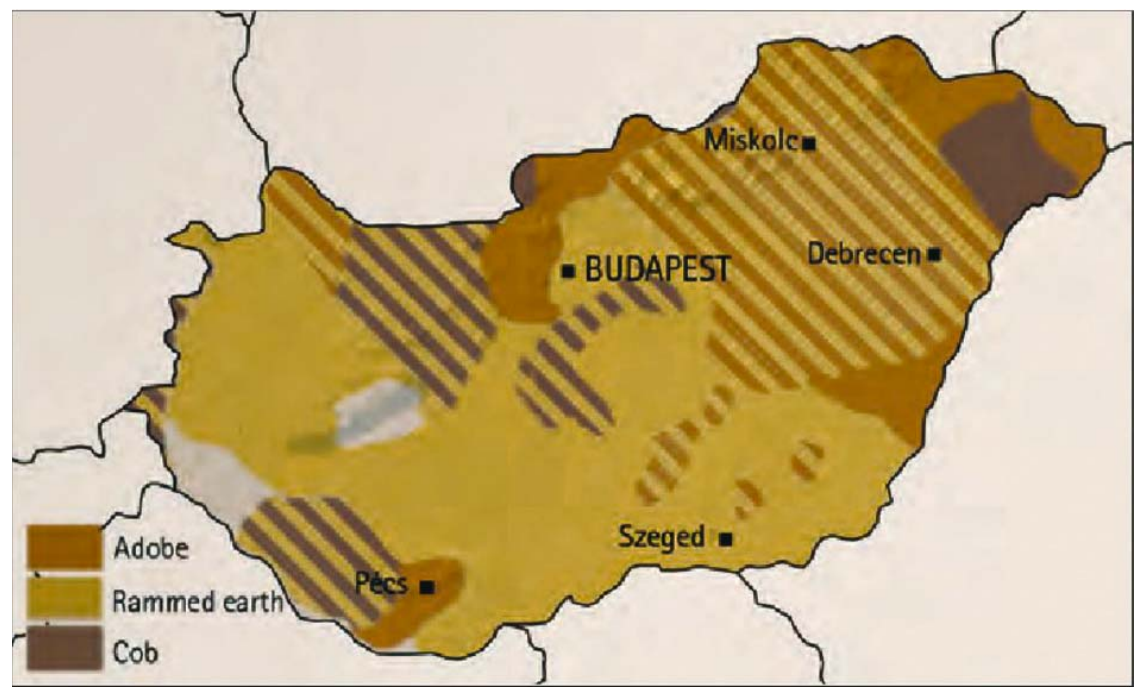

Fig.3. Map of Hungary where we can find earthen buildings

In Hungary, the earth as a cheap building material, reached to the center of attention at the moment when getting wood became difficult and expensive. Stimulating economic construction, using only half of the necessary wood for a house, it began in the eighteenth century. In the Carpathian Basin, by the late nineteenth century, earth and cob use to build walls has become a frequently used technique, with construction techniques adapted to the local material's characteristics. Wooden buildings remained in higher proportion in Seklerland area only and in the northern region (where vast forests are found).

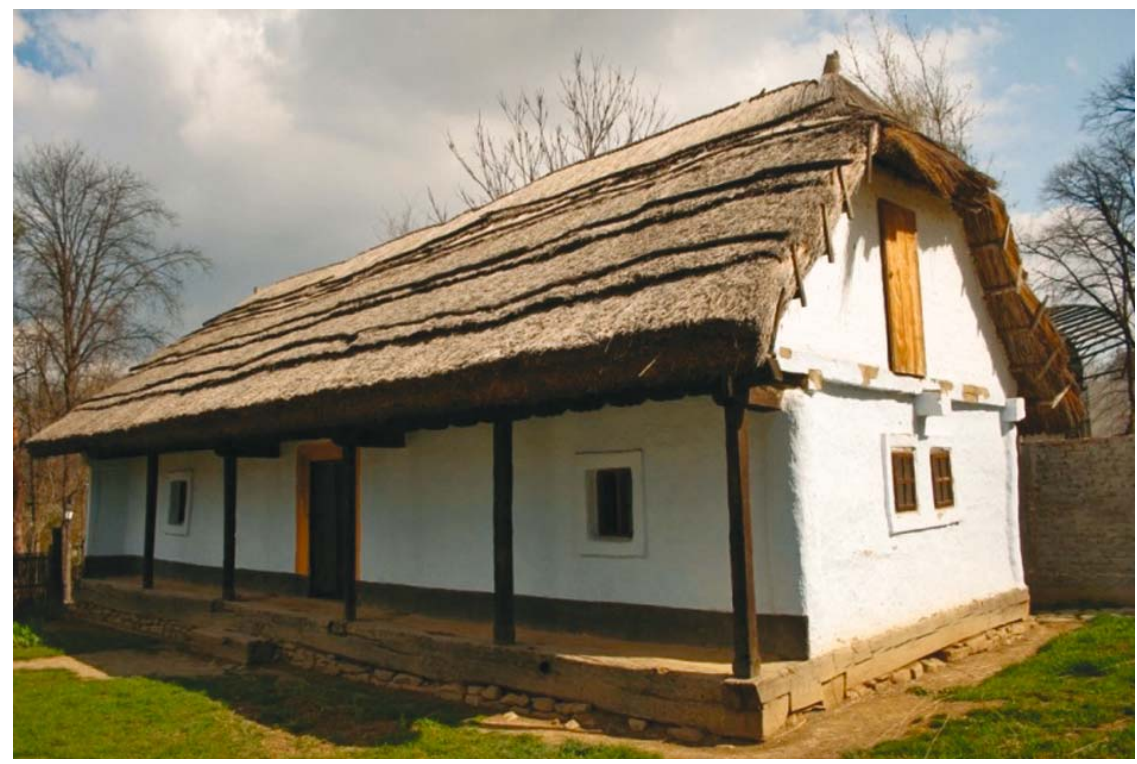

Fig.4. Earthen house from an Open air Museum 
Not only in outdoor museums in Hungary (Szentendre, Szenna, Szalafo, Zalaegerszeg Nyíregyháza, Szombathely, etc.), but also in villages as well it can be seen even today the varied types of walls of earth. There are places, for example Hollókő (Nógrád county) or Mezökövesd (Borsod-Abaúj-Zemplén county), where are remained authentic parts of the old villages built in the late nineteenth century and early twentieth century. Here, especially in household buildings, adobe was used for wall construction. In Hollókö, most of the houses are built on a foundation made of stone with adobe or with adobe bricks walls.

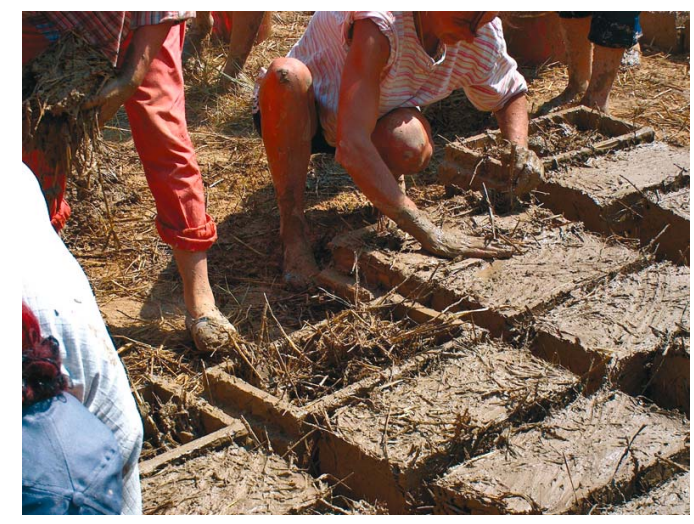

Fig.5. Adobe making - bricks

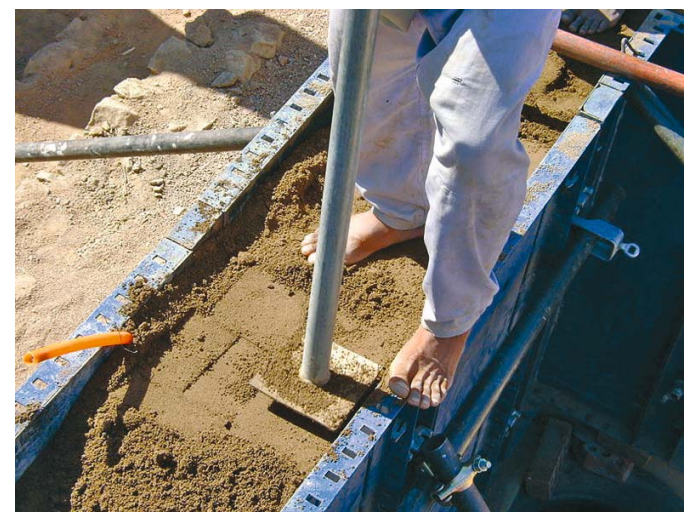

Fig.6. Rammed earth technique

In the early '50s, Professor Laszló Varga found that the Hollókő village is a typical village from the ethnographic region "palóc" from northern Hungary and decided that it has to be protected. Architects and ethnographic have produced complex documentation of the houses and households. There were taken place great restoration processes and protection of constructions in the village as rural monuments, through several projects between 1961-2012. The village was introduced on the UNESCO World Heritage Site List in 1987.[12]

The cob wall is made of clay mixed with straws, often used in Hungary. Piles of clay, the ball size, were mixed, with a fork with straw scattered on the ground, which, after drying, they were made manually. The authors of architecture books describe such houses in the south of the Danube and in the Hungarian Plain. The building technique of clay walls with straw in formwork, shows continuity of the technique of rammed earth walls. The cob walls have not been used in construction since the beginning of the nineteenth century.

Buildings that used rammed earth walls required as raw material clay, which was placed in a wooden frame, the same type being used and with walls of clay mixed with straws and for those made out of earth, widespread across the Danube and Little Plain.

The rammed earthen wall between wattles is similar to the simple wall of rammed earth, but it has reinforced stakes braids, braids that are not removed after the earth is rammed. This method, in "Hungarian style", became known during the war against the Turks. Until the late nineteenth century, it was very popular and spread between the Danube and Tisza and also spread beyond the Danube, in the in the Székely area and in the Transylvanian Plain.

The increase popularity of the organic architecture and environmental protection led to the implementation of traditional technologies in the modern architecture in Hungary. 
The houses are restored instead of being demolished, and new homes are built of earth. After the ecological villages came to public attention, there have been published articles on adobe constructions always seen in the Great Hungarian Plain. Due to the pioneering work of Balázs Nagy, some buildings of clay mixed with straw were made in Budapest and around. The goal was not to imitate rustic old buildings, but to preserve their values, which can be used today: natural materials, system of proportions, organic perspective. His house, built in 1973, was nominated for House of the Year in Hungary in 1986.

Tibor Jankovics uses rammed earth construction technology in Keszthely and through its neighbourhoods, following local traditions and adaptation to the environment.

The current situation in Hungary of earthen architecture suggests that there is a future for the recovery of traditional existing earthen houses and that these techniques have a place in the contemporary architecture because of its ecological and sustainable characteristics.[3][8][10][12][14]

\section{CONCLUSION}

Earthen architecture is one of the most original and powerful expressions of our ability to create a built environment with the available resources. It includes a variety of structures for the historical city centres and cultural landscapes. Its worldwide cultural importance is obvious and led to its placement in the spotlight.

Humanity heritage deserves protection and conservation by the international community. Currently, over 10 percent of the properties of the World Heritage include earthen structures. The material's availability and quality means it has great potential to contribute to poverty reduction and sustainable development. However, it is increasingly threatened by natural and human impacts (floods and earthquakes, industrialization, urbanization, modern construction technologies, disappearance of traditional conservation practices).

In Hungary, the rural vernacular heritage has represented an intense activity of research and conservation since the late nineteenth century. After 1882, when in Budapest was founded the Institute for Historical Monuments, the activity was spread even to remarkable and small churches built of simple materials. Research on vernacular architecture began with documenting the church buildings. After World War II, it was achieved the defence and preservation of rural monuments from the state. Ethnographers and architects worked hard so that the popular architecture protection (where we can find vernacular architecture) to be in the legislation in 1949. Researches have shown that archaic buildings are not Hungarian isolated constructions, in the course of time being a connection with the influences of European culture.

There are institutions and organizations well specialised (such as Forster Institute, Museum of Buildings, Open Air Museum in Szentendre, Ethnographic Museum in Budapest), which have similar activity as documentation, preservation and enhancement of the national cultural heritage. The experience of Hungarians experts in this area is a good model to be studied and adapted to be implemented as a solution to the vernacular heritage in Romania. 


\section{REFERENCES}

[1.] BARCA A.: Plastica arhitecturii rurale, Ad Libri Publishing, 2007

[2.] BERESCU C.: Earthen arhitecture in Romania, Terra Europae, Earthen arhitecture in European Union, Edizioni ETS, 2011

[3.] CSERI M., HORVÁTH A., SZABÓ Z.: Discover Rural Hungary, Hungarian Open Air Museum, Szentendre, 2007

[4.] DRAGOMIR V.: Conservarea si restaurarea arhitecturii vernaculare, Universitaria Publishing, 2012

[5.] GLIGOR L., COMAN D.: Case traditionale din Marginimea Sibiului - Indrumar practic de restaurare si intretinere, Uniunea Arhitectilor din Romania, 2011

[6.] IONESCU G.: Arhitectura populara romaneasca, Technical Publishing, 1957

[7.] MINKE G.: Construind cu Pamant - Proiectare si tehnologii pentru o arhitectura durabila, Simetria Publishing, Bucharest, 2008

[8.] GILYÉN N.: Az Erdélyi Mezöség Népi Épitészete, Terc Kiadó, Budapest, 2005

[9.] STANCIULESCU Fl., GHEORGHIU P., STAHL P., PETRESCU P.: Arhitectura populara romaneasca regiunea Dobrogea, Technical Publishing, 1957

[10.] NAGYNÉ BATÁRI Z.: An Exhibition is Born, Hungarian Open Air Museum, Szentendre, 2014

[11.] Arhiterra: Caietele de notite despre mesteri si mestesuguri, Simetria Publishing, 2010

[12.] DOBOSYNÉ ANTAL A., KOVÁCS D. : Hollókő öröksége szerk. ICOMOS Magyar Nemzeti Bizottsaga, Budapest 2013.

[13.] ICOMOS Magyar Nemzeti Bizottsaga

[14.] http://issuu.com/dida-unifi/docs/terra_europae_2143ee449be7ab

[15.] SABJÁN T., BUZÁS M.: Hagyományos falak, Terc Kiadó, Budapest, 2003.

[16.] BALASSA I. föszerk.: Magyar Néprajz IV. Életmód, Akadémiai Kiadó, Budapest, 1997

[17.] GYÖRFFY I.: Magyar falu, magyar ház, Akadémia Kiadó, reprint (1943), Budapest 1987.

\section{SOURCES OF PHOTOS:}

Fig.1.\&Fig.3.

http://issuu.com/dida-unifi/docs/terra_europae_2143ee449be7ab

Fig.2.

http://turism.bzi.ro/mai-mult-de-4-milioane-de-romani-locuiesc-ca-in-evul-mediu-in-case-din-chirpici-sau-paianta-27267

Fig.4.

http://www.muzeul-satului.ro/viziteaza-muzeul/51/cherelus-jud-arad-sec-al-xviii-lea

Fig.5.

http://middleearthhome.com/green-building/adobe/

Fig.6.

http://www.oregonlive.com/hg/index.ssf/2012/11/from_the_home_front_rammed-ear.html 